UDC 378.147:811

DOI https://doi.org/10.32840/1992-5786.2021.76-3.19

\author{
Yu. I. Samoilova \\ Candidate of Pedagogic Sciences, \\ Associate Professor at the Department of Humanities \\ Sumy Branch \\ of Kharkiv National University of Internal Affairs
}

T. M. Serhiienko

Candidate of Pedagogic Sciences, Associate Professor at the Department of Foreign Languages and Military Translation Hetman Petro Sahaidachny National Army Academy

\title{
FORMATION OF FOREIGN LANGUAGE COMMUNICATIVE COMPETENCE OF FUTURE LAW-ENFORCEMENT OFFICERS AND SERVICEMEN IN MODERN PROFESSIONAL TRAINING
}

The article substantiates the importance of possession of foreign language communicative competence by law-enforcement officers and officers of the Armed Forces of Ukraine as one of the main components of the professionalism of a modern specialist. It is noted that the active development of European integration processes has necessitated the modernization of training in accordance with the requirements established in the member states of the European Union. The foreign language component of the training program for lawenforcement officers and servicemen plays an important role in the process of modern higher education in the professional field. In the process of modern foreign language training, future specialists must not only master the language tools, but also learn to use them in order to solve effectively problems in their specialty.

The article emphasizes that the essence of a cadet's foreign language communicative competence is revealed in a certain level of foreign language proficiency, speech, military-professional and socio-cultural knowledge, skills and abilities that enable effective speech behavior depending on the functional factor of foreign language communication. It is also noted that foreign language communication creates the basis for cadet's communicative bicultural development.

It is determined that the most expedient in teaching a foreign language is a communicatively oriented competence approach. To form the skills of professional communication of cadets, a foreign language teacher should develop all types of their speech activities, use authentic language materials, domestic and foreign textbooks, modern audio, video and multimedia materials. It is advisable to conduct actively binary classes with the involvement of foreign representatives - specialists in law-enforcement or military field. Language training of cadets should not be limited only to classroom work; participation in speaking clubs is necessary for the development of speech skills. Properly organized independent work also plays an important role in the formation of foreign language communication skills because it gives cadets the opportunity to develop their professional knowledge, learn new professional terminology, and promotes the development of independence and initiative.

It is emphasized that in modern professional training it is necessary to avoid unified models of education. It is important to use professional role-playing and game communication of cadets.

Key words: competence, foreign language communicative competence, foreign language for professional purposes, professional training, cadet, law-enforcement activity, the Armed Forces of Ukraine.

Formulation of the problem. The changes taking place in the life of our country in recent years, in particular Ukraine's course towards European integration, have become a driving force in strengthening the process of learning foreign languages by future specialists in all fields. According to the strategy for the development of language education in Ukraine, the content of which is defined in the National Doctrine of Education of Ukraine in the XXI century, the system of continuing language education should ensure mandatory mastery of the state language, the ability to know native (national) and learn foreign languages. Education contributes to the formation of high language culture and language competence of citizens, respect for the state language and lan- guages of national minorities of Ukraine, tolerant attitude towards speakers of different languages and cultures [4, p. 3-9]. In the context of globalization of society, rapid development of international cooperation, expansion of international professional relations, the problem of formation and improvement of foreign language professional communicative competence of future law-enforcement officers and servicemen has become one of the priority areas of their training.

The topicality of this issue has led to a study on "The formation of foreign language communicative competence of future law-enforcement officers and servicemen in modern professional training".

Analysis of recent research and publications. Over the last decade, numerous research results 
have been published by educators on the formation of students' foreign language speaking skills. Problems of formation of foreign language communicative competence of specialists of different spheres were investigated in the works of Demchenko D. (legal profession), Kukhta I. (tourist sphere), Hridnieva L. (law enforcement officers). A number of scientific publications by Kanova L., Chyrva A., Shcherba O., Yefimova O., Zakharova L. and others are devoted to the problematic issues of reforming and improving the language training of cadets of higher educational institutions. However, the analysis of the pedagogical foundations of the formation of foreign language communicative competence of cadets taking into account modern requirements have not been the subject of separate scientific research. This led to the urgency of choosing the topic of this scientific work.

The purpose of the article is to substantiate the importance and main aspects of the formation of foreign language communicative competence of future law-enforcement officers and servicemen taking into account modern professional requirements.

Presenting the main material. In the context of expanding the international relations of our state with other countries in various spheres of economic and socio-cultural activities, the formation of foreign language communicative competence of law-enforcement officers becomes especially relevant. This need arises due to the urgency of effective cooperation with experts from other countries against the background of transnational crime and crimes of an international nature. All this necessitates the study by law-enforcement officers not only the legislation of Ukraine, but also the legal framework of other states, which can be presented in a foreign language, as well as skills of communication with law-enforcement agencies of other states in international cooperation.

The constant participation of the Armed Forces of Ukraine in peacekeeping and security operations, the reorientation of the training of troops according to NATO standards, the expansion of international contacts require an adequate level of command of personnel in foreign languages [5, p. 1]. The need to improve the language of Ukrainian servicemen is substantiated in the "Basic principles of language training of personnel in the system of the Ministry of Defense of Ukraine" [5]. According to this document, the main purpose of English language cadets is to develop and improve their military skills in the military professional profession in accordance with the requirements of the NATO language standard STANAG $6001[5$, p. 6].

The military and law-enforcement spheres are quite close in its nature, so we will consider the formation of foreign language communicative competence of future law-enforcement officers and servicemen as a single concept.

First of all, it is necessary to understand the basic concept of our article, namely foreign language com- municative competence. The scientific literature on communicative competence distinguishes the concepts of "competence", "competence", and "communication". Having analyzed them, we can state that the communicative competence of a future specialist consists of three main features: 1) practical possession of an individual stock of verbal and nonverbal means to update the informational, expressive and pragmatic functions of professional communication; 2) the ability to vary the means of communication and communication processes in connection with the dynamics of the situation of professional communication; 3 ) the ability to prepare speech acts in accordance with language and speech norms [7, p. 108].

We also share the opinion of researcher L. Hridnieva, who considers the concept of "foreign language communicative competence of future law enforcement officers" as a holistic integrative formation of personality, which is a separate component of professional communicative competence and consists of appropriate language, speech and sociocultural competence, and is formed on the basis of the approach "knowledge - their practical implementation" in the context of the created value-semantic communicative environment and allows to realize intercultural communicative function of future law-enforcement officers in the course of their professional activity [1, p. 11].

The formation of foreign language communicative competence of future professionals occurs during the process of learning a foreign language for professional purposes while studying in a higher education institution. The discipline "Foreign Language" and "Foreign Language for Professional Purposes" is an integral part of professional training and an organically connected prerequisite for the full development of a future specialist. The main purpose of teaching a foreign language for professional purposes is the formation of the necessary communication skills in the areas of professional communication both orally and in writing, skills of practical knowledge of a foreign language in various speech activities to the extent of professional needs, mastering the latest professional information through foreign sources.

The ultimate goal of learning a foreign language is the formation of cadets' readiness and ability for intercultural communication, practical mastery of foreign language communicative competence, i.e. the ability to compare language tools with specific goals, situations, conditions and objectives of speech communication.

At all stages of foreign language communicative competence formation of future military and law-enforcement officers it is necessary to create conditions for their professional development. Since both law-enforcement and military activities are communicative in nature, the most appropriate in teaching a foreign language is a communicatively oriented competence approach. The formation of foreign language 
communicative competence during the study of a foreign language of future law-enforcement and military officers should be carried out in the speech-communicative foreign language environment, aimed at ensuring the maximum relevance of speech and professional behavior of the latter [2, p. 35-39].

To form the skills of professional communication, a foreign language teacher should develop all types of speech activities of cadets (listening, speaking, reading and writing); use authentic language materials, domestic and foreign textbooks, modern audio, video and multimedia materials; control the knowledge of students at all stages of education. From the first year of study it is necessary to take into account the specialization of cadets to successfully master the vocabulary of the future specialty. This approach significantly improves the assimilation of language material in the process of language activities, in particular during the reading and translation of professional texts, taking into account both lexical and linguistic aspects.

The process of learning a foreign language should be based on close interaction with other professional subjects, thus implementing the principle of integrity and practical orientation of language training. Moreover, it is important to involve foreign specialists of the relevant specialty to the conducting of the classes. That is, it is advisable to conduct binary classes. This type of activity has several positive aspects: 1 ) it helps to overcome the language barrier; 2 ) it promotes the application of already acquired professional skills and abilities to solve certain simulated problem situations using a foreign language; 3 ) it increases the motivation of cadets to learn a foreign language.

When teaching a foreign language in a higher education institution with specific learning conditions, it is important to use popular science articles that correspond to the future profession. Therefore, in the educational process, the process of working with this material involves the following tasks: acquaintance with military or police scientific publications, clarification of new trends in foreign research in the military or police system, search and selection of materials for scientific and practical activities. The internal condition of reading popular science literature is communicative and cognitive activity. Therefore, professionally oriented reading is one of the priority types of language activities in the training of cadets, because it allows future military and law-enforcement professionals to use all the necessary media.

In our opinion, it is extremely important to master the general military and police terminology. Particular attention should be paid to the study of international vocabulary, abbreviations, ambiguous words-terms that are characteristic of the specialized literature.

Another type of effective way to expand the cadet's terminological vocabulary is independent work. Properly organized independent work gives applicants the opportunity to develop their knowledge about professional activities, introduces new professional terminology, and promotes the formation of such professional qualities of personality as independence and initiative.

At the present stage, a necessary condition for learning is the introduction of such methods that would more effectively reveal the potential of cadets, their intellectual, creative and moral qualities, increase motivation to learn a foreign language, enhance their cognitive activity, and encourage creative search and self-improvement.

Scholars argue that modern language training should involve the abandonment of unified models of learning. It is important to use professional role-playing and game communication of cadets [3, p. 11; 6, p. 6]. Therefore, it is important for teachers to be able to combine different modern technologies of teaching English, and to use creative forms of educational activities.

Language training should not be limited only to classroom activities. It is necessary to involve cadets in speaking clubs, which should be conducted with the involvement of foreign representatives. Such speaking clubs give cadets the opportunity to communicate in English, make presentations, as well as operate with various professional and everyday vocabulary, gain experience in professional matters. Among the fundamentally important parameters of communication are motivation, activity, purposefulness, novelty (which is manifested in changing the subject of discussion - tasks) and individualization (taking into account the life experience and interests of cadets). Speaking club is one of the additional means to improve professional communication in a foreign language and help cadets form professional communicative competence. Learning a foreign language goes far beyond compulsory education. The non-language university program is aimed at developing general critical thinking skills, problem solving, presentation of ideas and so on. An additional opportunity to communicate in a foreign language helps students master the language according to their specialization, life plans and specific needs. Speaking Club aims to combine classroom and extracurricular work, which helps to improve language and speech skills.

Conclusions and prospects for further research. The expansion of integration processes in international military and law-enforcement cooperation determines the need of the Armed Forces of Ukraine and the National Police for officers ready to carry out foreign language intercultural communication. Preparation for this type of communication involves the formation of foreign language communicative competence of cadets while learning a foreign language. The cadet's foreign language communicative competence is a complex, integral personal formation, which enables his ability to communicate in the process of foreign language professional-oriented 
communication, as well as to create and manage discourses on professional topics. The essence of the cadet's foreign language communicative competence is revealed in a certain level of knowledge of a foreign language, speech, socio-cultural and professional knowledge, skills and abilities that allow to vary speech behavior depending on the functional factor of foreign language communication. Modern vocational education requires a specialist to be flexible, to have not only professional knowledge but also social skills.

The process of mastering a foreign language should include interactive, creative, problematic tasks, be diverse to promote the development of intelligence, research and creative thinking of future law-enforcement officers and servicemen, as well as the ability to reasonably and appropriately vary their language skills depending on psychological communication factors.

\section{References:}

1. Hridnieva, L.M. (2010). Formation of foreign language communicate competence of future lawenforcement officers (Extended abstract of $\mathrm{PhD}$ dissertation). Luhan. nats. un-t im. T. Shevchenka, Luhansk, Ukraine. [in Ukrainian].

2. Diahilieva, L.D. (2016). The problem of language training of future law-enforcement officers in new conditions of professional activity. In Urgent scientific researches in modern world.
Proceedings of the XIV International scientific conference (pp. 35-39). Pereiaslav-Khmelnytskyi, Ukraine. [in Ukrainian].

3. Yefimova, O.M. (2015). Cadets' training to language interaction in professional and sociocultural spheres of communication. In Modern tendencies of foreign language for professional purposes teaching in high school. Proceedings of the International scientific conference (pp.37-39). Kyiv, Ukraine: NTUU «KPI». [in Ukrainian].

4. Nationalna doctryna rozvytku osvity Ukrainy u Xxi stolitti. (2002, No. 6). Osvita Ukrainy, 3-9. [in Ukrainian].

5. Osnovni zasady movnoi pidgotovky osobovogo skladu v systemi Ministerstva oborony Ukrainy [The basic principles of language training of personnel in the system of the Ministry of Defense of Ukraine]. Vykhidnyi document Ministerstva oborony Ukrainy, 154/z/84, 8 serpnia 2019 r. [in Ukrainian]

6. Chyrva, A.V. (2008). The improvement of the language training system and language testing of cadets of higher military educational institutions. Ivan Ohiienko i suchasna nauka ta osvita, 198-207 [in Ukrainian].

7. Yakovenko, N.V. (2019). The formation of foreign language communicative competence of cadets of higher military education institutions. Innovative pedagogy, 18, Vol.3, 107-110. [in Ukrainian].

Самойлова Ю. І., Сергієнко Т. М. Формування іншомовної комунікативної компетенції майбутніх працівників правоохоронних органів та військовослужбовців у сучасній професійній підготовці

У статті обгрунтовано важливість володіння працівниками правоохоронних органів та Збройних сил України іншомовною комунікативною компетенцією як одним з основних складників профресіоналізму сучасного фрахівця. Зазначено, що активний розвиток євроінтеграційних процесів спричинив необхідність модернізувати підготовку фрахівців відповідно до вимог, встановлених у державах - учасницях Європейського Союзу. Іншомовна складова частина програми підготовки працівників правоохоронних органів та військовослужбовців відіграє важливу роль у процесі сучасної вищої освіти за профресійним спрямуванням. У процесі сучасної іншомовної підготовки майбутні фрахівці повинні не тільки опанувати мовними засобами, а й навчитися використовувати їх для ефективного розв'язання завдань за своєю спеціальністю.

У статті підкреслюється, що сутність іншомовної комунікативної компетенції курсанта розкривається в певному рівні володіння ним іноземною мовою, мовленням, військово-професійними та соціокультурними знаннями, уміннями і навичками, що дають можливість еффективно здійснювати мовленнєву поведінку залежно від фрункціонального чинника іншомовного спілкування. Також зазначено, що іншомовне спілкування створює підгрунтя для комунікативного бікультурного розвитку курсанта.

Визначено, що найбільш доцільним у навчанні іноземної мови є комунікативно орієнтований компетентнісний підхід. Для фрормування навичок профресійного спілкування курсантів викладачеві іноземної мови варто розвивати всі види їх мовленнєвої діяльності, використовувати автентичні мовні матеріали, вітчизняні та закордонні навчальні посібники, сучасні аудіо-, відео- й мультимедійні матеріли. Доцільним $є$ активне проведення бінарних занять із залученням іноземних представників фрахівців цієїгалузі. Мовнапідготовкакурсантівнеповиннаобмежуватисятількиаудиторноюроботою; необхідним для розвитку мовленнєвих вмінь $є$ участь у розмовних клубах. Належно організована самостійна робота теж відіграє важливу роль у формуванні навичок іншомовного спілкування, оскільки дає можливість курсантам розвивати свої професійні знання, вивчати нову фахову термінологію та сприяє розвитку самостійності та ініціативності.

Наголошено на тому, що в сучасній профресійній підготовці необхідно уникати уніфрікованих моделей навчання. Важливим є застосування професійно-рольового та ігрового спілкування курсантів.

Ключові слова: компетентність, іншомовна комунікативна компетентність, іноземна мова за профресійним спрямуванням, професійна підготовка, курсант, правоохоронна діяльність, Збройні Сили України. 